\title{
WOMEN'S VOICE AND IMAGES IN FOLK TALES AND FAIRY TALES
}

\author{
Luma Ibrahim Al-Barazenji ${ }^{\star}$ \\ *Assist. Prof. Dr. College of Basic Education / Diyala University/ Iraq \\ lumahh50@gmail.com
}

\begin{abstract}
The role of women in folktale and fairytale has a pioneering consideration. It presents their effective voices and presence through being queen, princess, maid, stepmother, and witches. Topics like evil and good are discussed prolifically through different female images to legitimize the representation and value of women in many cultures. Scholars point out that the representation of women in folktale and fairytale has been based on certain basic images of passivity, beauty, wickedness, goodness, strength, and power. Heroines of such tales are popularized by their powerful figures as being cruel stepmothers or wise witches. These stereotypical female characters appear so effective in rescuing or changing destiny of other young women. To feminism, these tales refer explicitly to the important images of woman that seems to stress the significant role of her in societies. Moreover, feminist movement tackles the transformation of the female voice of these tales from marginalization to centralization. In one hand, feminist scholars rejected the indifference of societies when women are placed in subvaluable position, and on the other hand, they challenged the patriarchal authority to reevaluate the role of woman. Hence, the figure of queen, princess, maid, witch, stepmother, or godmother are representatives of women-centered tales that modify their minority and being object to majority and the subject of the action. This elite concept is focused by the researcher through taking into consideration the examples of wicked stepmother, godmother, innocent princess, and clever maid in some tales such as Cinderella, the Snow White and the Seven Dwarfs, The Seven Swans, Beauty and the Beast, and Alice in Wonderland.
\end{abstract}

Keywords: Folktale, Fairytale, Dream Stories

\section{INTRODUCTION}

The fairy and folk tales are associated with women as they are tales of old mothers and grandmothers. Fairy and folk tales can be devoted to enhance the concept of women's self-expression because the protagonists of these tales depict powerful female's personality. Simultaneously, strong feminine characters could be found in real and imaginative tales in that both images reflect the influential voices of women. In 1970s, Alison Lurie asserts in her article Fairy Tale Liberation that "folktales and fairy tales can advance the cause of women's liberation, because they depict strong females" (1). Women's liberation within fairy and folk tales records female's popularization as powerful and influential subjects that have ability to change the life line of other characters. They appear to grip the events of the stories and to control the tale's text with their good or evil spell.

\section{FEMINISM AND FAIRY TALES}

\subsection{Images of Women}

Feminist fairy tale studies emphasize the identification of women's voice in these tales and their controlling images in contrast with the male-dominated influence. For instance, a king on a quest to find a queen for his lost wife indicates how that replaceable woman plays an important role and heroic presence in the life of her 
king and kingdom. While the search for another man instead of the lost husband has less heroic, influential, and expressive importance. Moreover, women-centered tales or dream stories collected from women storyteller emphasize the role of women in depicting strong feminine characterization. Hence, scholars insist in their quest on the important role of woman in fairy and folk tales to focus on shifting from woman's passivity to the positivity. This concern in woman's role as storytellers emerges from the fact that many wellknown female writers enrich literary genre with folk stories such as Zora Neale Hurston (1891-1960), when she documented African American folklore and traditional tales of the Blacks in her novel Mules and Men (1930) as a treasury of black American's folklore or Negro folklore. Alice Walker (1944- ), examined the popularity of the African American traditions when she included tales and accent of her folk in her novel The Color Purple (1983) insisting that these tales reflect the creativity and self-expression of black women and their participation in telling and resurrecting black traditions. Margaret Mills (1946 - ) studied the relationship between gender and storytelling to ensure a significant finding "that men tend to tell stories about men while women tell stories about women and men" (2). Marina Warner (1946 - ), in her study From the Beast to the Blonde: On Fairy Tales and Their Tellers (1994), points out that women have a role in rising their voices in storytelling. In both tales of Charles Perrault and the Brothers Grimm, women were emerged as a storytellers and heroines as they reflect the producer of the prolific sort of literature.

Women writers strongly assert that women's images and voices challenged the male-dominated authority when they devoted their effort to expose their femininity whether through passive-beauty characterization or through their kindness and charity. In most of this storytelling, women try to replace the image of weak fairytale heroine with a self-independent and brave one. Snow White and the Seven Dwarfs (1937), Sleeping Beauty (1959), and Cinderella (1950), present woman's image in a most brave and influential figure who transforms the fatal end into fruitful days. On the other hand, Andrea Dworkin (1946-2005), asserts in her book Woman Hating (1974), that these tales have a passive effect on women because they depict women as wicked, weak, and shallow. Similarly, Susan Brownmiller in her book Against Our Will: Men, Women and Rape (1975), clarifies that tales like Cinderella, Sleeping Beauty, and Snow White emphasize the idea of woman's victimization ${ }^{(3)}$, and the unawareness from the destructive part of these tales.

During the 1970s, scholars reaffirmed the significance of fairy and folk tales by reevaluating them from romantic point of view. In 1979, Karen E. Rowe (1945) focuses on the role of women and tales in affirming and encouraging concepts like marriage, love, and romance. Rowe points out those lovable figures of these tales present romantic materials of eroticism, happy marriage, and devoting love that affected not only children but also the lives of adults. Rowe also asserts that women in fairy tales began to challenge the mores of their societies and question the romantic ideals ${ }^{(4)}$. She shows that most modern women increasingly question the continuity of those romantic ideals in the modern societies in that "all men are not princes" ${ }^{(5)}$. To Rowe, fairy tales left women in an ambiguous position swaying in loss between romantic ideals and the realities of their cultures:

Today women are caught in dialectic between the cultural status quo and the evolving feminist movement, between a need to preserve values and yet to accommodate changing mores, between romantic fantasies and contemporary realities...But one question remains unresolved: do we have the courageous vision and energy to cultivate a newly fertile ground of psychic and cultural experience from which will grow fairy tales for human beings in the future? ${ }^{(6)}$.

As an active feminist, Rowe describes these tales as a source of an "awesome imaginative power" that archives a serious attempt to re-emphasize the equality between man and woman. She continues in her argument that although these fairy tales consider as a rejuvenated style of romantic fantasies, yet they reflect a cultivated feminine identity and emerging samples of female self-expression:

One feels particularly the importance of not limiting the female imagination to female models...small boys can use the female model of helplessness in fairy tales to reduce their anxieties and unmentionable fears; similarly, young girls should be able to use male models to enhance their feelings of daring and adventure...To choose only the most obvious example, consider the many Grimm fairy tales employing the 
theme of the "three brothers". What if the girl could conceive of herself as the youngest of the three? Powerless, scorned, the one from whom least is expected...because of virtues clearly "feminine"- animal loving ${ }^{(7)}$.

In Colette Dowling's volume of 1981, The Cinderella Complex: Women's Hidden Fear of Independence, Dowling points out that the story does not reflect dreamy girlish interests, but rather it shows a psychological suffering and the false familial relationships. To Dowling, Cinderella presents an actual story that deals with a sociological treatment. Thus, many scholars investigate that fairy and folk tales prepare their children readers and listeners for real women's self-expression and identification. To a certain extent, this idea is clearly discussed by feminist interpretations because such tales include strong heroines, wise witches, beautiful girls, and decision-maker characters.

\subsection{Women's Voice in Fairy Tales}

Although most scholars agree that fairy tales are a reflection of modern cultivated women's style, yet they assert that women's images were different in fairy tales. Suzanne Barchers's Wise Women: Folk and Fairy Tales from Around the World (1990), Virginia Hamilton's Her Stories: African American Folktales, Fairy Tales, and True Tales (1995), and Kathleen Ragan's Fearless Girls, Wise Women, and Beloved Sisters: Heroines in Folktales From Around the World (1998), present various images of women who appear strong, active, submissive, loving women, helpful, wise, and wicked. As wives and mothers, women depict mythical and influential characters as queen, goddess, or helpful witch.

It may be obvious that the second wave feminism considers fairy tales as evidences of women's victimization. To its activists, these tales are objects for the real suffering of this generation because women are subjects of submissiveness, silence, patriarchal authority, or physical and psychological violence. In Cinderella, the heroin is subjugated to the physical beating and the spiritual humiliation. She is forced to repress her feelings and to do all home duties under the oppression of her stepmother. In Beauty and the Beast, Beauty sacrifices herself by going to the Beast's castle and making a deal for marriage. Thus, Jeanne-Marie Leprince de Beaumont, the author of this tale, points out that the mark of beauty for a female is to be found in her submission, obedience, humility, and patience ${ }^{(8)}$. To Beaumont, "young women should be educated and encouraged to be intelligent, not just viewed as fodder for marriage" (9). In Cinderella, goodness is still overwhelming the tale although Cinderella suffers being servant and victim. She represents the real and symbolic of victimization of a girl who lost her mother and lives the injustice of her stepmother and stepsisters

The suffering servant reflects the reality of earlier times when women struggled against being female. Cinderella was met by social and familial denial that was translated to physical and social violence. To feminism, Cinderella's weakness and silence are her real strength. Her patience empowers her and fills her with energy to struggle and survive ${ }^{(10)}$.

Third wave feminism discusses folk and fairy tales according to the wave interests in sexuality, gender, and power. To third wave feminist activists, fairy tales address contemporary interests and aim to gather creativity and imagination, magic and realism. Huang Mei asserts in her study Transforming the Cinderella Dream: from Frances Burney to Charlotte Bronte (1990), that Cinderella has functioned as a double-edged story because it reflects woman's subordination to oppression and it explores woman's sense of individual dignity and self-realization ${ }^{(11)}$.

Most feminine figures in fairy tales appear as a witch, an enchanted princess, a maid, or an elf. These roles seem to "embrace certain characteristics traditionally linked to femininity" ${ }^{(12)}$. The witch in Sleeping Beauty has been given traits such as strength and wickedness in regardless to gender role. In Ursula K. Le Guin's Earthsea Series from 1968 to 1972, who gathers between folk and fairy tales, Guin intends to present woman in the first three books as weak and inferior because she has to submit to man's authority and superiority. In the forth book Tenar directs her questions about men's authority to a witch who answers her with prophetic words for future women's identity: 
A man's in his skin...like a nut in its shell...It's hard and strong, that shell, and it's all full of him. Full of grand man-meat, man-self. And that's all. That's all there is. It's all him and nothing else, inside...a woman's a different thing entirely. Who knows where a woman beings and ends? Listen...I have roots; I have roots deeper than this island. Deeper than the sea, older than the raising of the lands...no one knows, no one can say what I am, what a woman is, a woman of power, a woman's power, deeper than the roots of trees, deeper than the roots of islands, older than the Making, older than the moon ${ }^{(13)}$.

To the witch, woman represents everything. She has the roots that are deeper than those of all creatures and her power is unlimited which is not a part of man's power. The witch's recognition of her power and voice confidently leads to improve her representation from marginalization to centralization as a triumphant feminist. By using various sorts of evil, the witch uses that magical power to increase her effective female task over men's.

In Sleeping Beauty, witch's evil competes with fairy's goodness. As a part of her influential authority, the witch's spell turns the events of the tale that needs other plans from good fairies to change a deadly sleeping into lively awakening. In this tale, women's voices and power are in conflict and real fighting. Two different feminine images struggle to improve the fittest. Good fairies, the image of evil destroyer, believe in the power of true love through breaking the spell of the witch's devilish gifted to the princess Aurora; "the fitful prophecy you'll keep. And from this slumber you shall awake, when true love's kiss the spell shall break" ${ }^{(14)}$. Although the witch's power guarantees her evil overwhelming and floating spirit, yet, the good fairy has her special spell to protect, care for, and develop events into just and happy ends. Nevertheless, casting of spell in Cinderella is changed into a wishing one which breaks the obstacles to happiness. The feminine role of the fairy helps Cinderella to empower herself with evitable dreams and hopes. Without this womanly help, Cinderella could never get her transformative image. In Cinderella, feminine characterization is not limited to the helpful fairy, but also to the oppressive role of her stepmother. The tyranny of the replaceable mother leaves Cinderella in a repressed freedom. Cinderella's silent beauty is increased by another feminine's authority. She was subjugated to gender and class oppression. Women's power in Cinderella offers a general outlook of stepmother's social authority that looks for wealthy and prestigious security. According to feminist point of view, the common theme in Cinderella is the conflict between feminine powers. The two versions of evil and good represent the polemic voices of women. In Cinderella's story, woman is the desirable character in that woman identifies and enhances the value of other woman. The role of godmother helps Cinderella to transform her fear of independence into a visible image and a speakable voice. The fairy godmother performs as a saver who contributes another image for Cinderella than being passive and victimized. To feminism, the process of the transformation in Cinderella's case is the meaning of emerging self-expression and identification offer a long time of silence and victimization. It is an identity that willingly transforms to be creative and personalized. Hence, the fairy godmother intervenes to redress the imbalance of the tale ${ }^{(15)}$. As a female fairy, the godmother stands in implicit contrast to another image of woman. She helps Cinderella to realize that her ambitions hide behind her silence and submissiveness although her role is depersonalized and marginalized to the realm of ghostly apparitions ${ }^{(16)}$. More importantly and dramatically, Cinderella represents a female agency in transforming woman's victimization into independence and self-expression. On the other hand, feminists passively consider that the main female role in Cinderella is a destructive one because it represents woman's submission to the patriarchal authority. Moreover, Cinderella's abuse is her passive familial tolerance in waiting to be rescued by power and presence of man ${ }^{(17)}$. To feminists, Cinderella finds her only outlet in mirage as a reward for her long patience but not another option to develop or transfer her identity into the best. In addition, the end of mirage promotes the idea that only a wealthy man could bring and make woman happy in regardless to any emotional respects.

Feminist readings of fairy tales such as Snow White and the Seven Dwarfs, Sleeping Beauty, and Cinderella, point out that these tales are judged wrongly when girls appear as sweet, beautiful, blond, and young who are rescued by other forces as if they are incapable for rescuing by themselves ${ }^{(18)}$. Hence, Lois Tyson continues: 
The plot thus implies that marriage to the right man is a guarantee of happiness and the proper reward for a right-minded young woman. In all three tales, the main female characters are stereotyped as either "good girl" (gentle, submissive, virginal, angelic) or: bad girls" (violent, aggressive, worldly monstrous). These characterizations imply that if a woman does not accept her patriarchal gender role, then the only role left her is that of a monster ${ }^{(19)}$.

In two of these stories, feminine sexuality seems to be dormant in deathlike slumber that could be never awakened unless a male power or a patriarchal authority interferes to change the situation. This result encourages the patriarchal ideology when women are viewed in terms of either good or bad according to the patriarchal orders. Woman is good if she obeys and accepts these orders, if she does not, she is out of order and deserves to be defined as witch or wicked.

Josephine Evetts-Secker (1942- ) tackles another sociocultural subject that can be found in folk and fairy tales. Orphanage and exiled orphan mark the creation of identity and self-expression. To Evetts-Secker, selfidentification lies in an isolated place in that most victimized princess or girls develop their inner ability and identity in an exiled orphanage. Such a place helps Snow White to establish her own identity and relationship with other common people, dwarfs, to experience independence. Being in a forest with strangers encourages the little princess to reach full recognition that her identity needs another kind of fulfillment away from the prestige of her father's castle. To feminists, Self-definition and self-expression are born from deprivation and isolation. Moreover, orphanage develops, to a certain extent, a balance of fulfilling and satisfying. Hence, this balance fosters the weak and fragile beautiful princess to another rebirth of powerful identity. Thus, in most fairy tales, orphanage creates a yearning for completion and self-reconciliation. In Hansel and Gretel, the children are rejected and left by their parents to live isolated in a forest, yet they accept their strange and hard environment to deal with everyday life problems in an exile denial.

According to the related association between fairy and folk tales and women, the paper concludes that woman's identity was modified from margin to center with an important fact that these tales were associated primarily with men collectors such as Charles Perrault or the Brothers Grimm. "What a woman reads in her mirror is the tales men tell about woman-Madonna and whores, saints and witches, good little girls and wicked queens" ${ }^{(20)}$. Women are mostly divided in two categories in fairy tales, the good victimized and submissive women, and the bad, wicked, and authertative women who are their destructive deeds are in fight with those of godmother fairies. In this sense, fairy tales serves as a persuasive didactic model for women: they teach patience and sacrifice ${ }^{(21)}$. On the other hand, feminists assert that these should be a serious challenge against the cultural ideals of subordinating women in most of romantic fairy tale versions. Finally, in most of feminists' points of view, fairy tales are another chance to create woman's voice and to develop self-expression.

\section{Notes}

1.(qtd) Donald Haase, "Feminist Fairy-Tale Scholarship". In Fairy Tales and Feminism: New Approaches. Edited by Donald Haase, Wayne State University Press, 2004, pp: 1-36, p.1

2.Haase "Women". In The Grean Encyclopedia of Folktales and Fairy Tales: Q-Z. Edited by Donald Haase. Greenwood Press, 2008, pp: 1036-1040, p. 1039

3.lbid. p. 3

4.Karen E. Rowe. Feminism and Fairy Tales. Radcliffe College, 1978, p. 211

5.lbid. p. 222

6.Ibid. p. 223

7.Ibid. p. 147

8.Jack Zipes. Fairy Tales and the Act of Subversion: The Classical Genre for Children and the Process of 
Civilization (New York: Wildman Press, 1983, p. 38, 40-41

9.Jerry Griswold. The Meaning of Beauty and the Beast: A Handbook. Broadview Press. Ltd. 2004, p.64.

10.Ann Ulanov and Barry Ulanova . Cinderella and her Sisters, The Envied and the Envying (Philadelphia; The Westminster Press, 2007, p.69

11.Donald Haase "Feminist Fairy-Tale Scholarship". In Fairy Tales and Feminism: New Approaches. Edited by Donald Haase, Wayne State University Press, 2004, pp: 1-36, p.20

12.Roberta S. Trites. Waking sleeping Beauty; Feminist voices in children`s. Novels. lowa City; The University of lowa press, 1997, p.5

13.(qtd), Ibid .p.132

14.Mark I. Pinsky. The Gospell According to Disney. Kentuck: Westminster John Knox Press, 2004, p. 75

15.David. Pace "Beyond Morphology: Levi-Strauss and the Analysis of Folktales". In Cinderella, a Casebook. Edited by Alan Dundes Wisconsin: The University of Wisconsin

Press, 1982, pp: 245-259, p. 255

16.Jeanne Wiley "Rewriting "Cinderella": Envisioning the Empowering Mother-Daughter Romance". In Mothers and Daughters: Connection, Empowerment, and Transformation.

Edited by Andrea O' Reilly and Sharon Abbey. Boston: Rowman and Littlefield Publishers Inc., 2000, pp: 91102 , p. 93

17.Lois Tyson. Critical Theory Today: A User-Friendly Guide. New York: Routledge Taylor and Francis Group, $2^{\text {nd }}$ edition. 2006, p. 88

18.Ibid., p. 89

19.Ibid.

20.Ellen Cronan Rose. Fairy Tale. Detroit, MA: Wayne State University Press, 1983, p. 211

21.Susanne Gruss. The Pleasure of the Feminist Text: Reading Michele Roberts and Angela Carter. Nurnberg: Friedrich-Alexander University, 2009, p. 197

\section{REFERENCE LIST}

Cronan, Ellen Rose. Fairy Tale. Detroit, MA: Wayne State University Press, 1983

Griswold, Jerry. The Meaning of Beauty and the Beast: A Handbook. Broadview Press. Ltd. 2004

Gruss, Susanne. The Pleasure of the Feminist Text: Reading Michele Roberts and Angela Carter. Nurnberg: Friedrich-Alexander University, 2009

Haase, Donald, "Feminist Fairy-Tale Scholarship". In Fairy Tales and Feminism: New Approaches. Edited by Donald Haase, Wayne State University Press, 2004

Haase, Donald, "Women". In The Grean Encyclopedia of Folktales and Fairy Tales: Q-Z. Edited by Donald Haase. Greenwood Press, 2008

Wiley, Jeanne, "Rewriting "Cinderella": Envisioning the Empowering Mother-Daughter Romance". In Mothers and Daughters: Connection, Empowerment, and Transformation. Edited by Andrea O' Reilly and Sharon Abbey. Boston: Rowman and Littlefield Publishers Inc., 2000

Pace, David. "Beyond Morphology: Levi-Strauss and the Analysis of Folktales". In Cinderella, a Casebook. Edited by Alan Dundes Wisconsin: The University of Wisconsin Press, 1982

Row, E. Karen. Feminism and Fairy Tales. Radcliffe College, 1978 
Trites, S. Roberta. Waking sleeping Beauty; Feminist voices in children`s. Novels. lowa City; The university of lowa press, 1997

Tyson, Lois. Critical Theory Today: A User-Friendly Guide. New York: Routledge Taylor and Francis Group, $2^{\text {nd }}$ edition. 2006

Wiley, Jeanne "Rewriting "Cinderella": Envisioning the Empowering Mother-Daughter Romance". In Mothers and Daughters: Connection, Empowerment, and Transformation. Edited by Andrea O' Reilly and Sharon Abbey. Boston: Rowman and Littlefield Publishers Inc., 2000

Ulanov, Ann and Barry Ulanova. Cinderella and her Sisters, The Envied and the Envying (Philadelphia; The Westminster Press, 2007

Zipes, Jack. Fairy Tales and the Act of Subversion: The Classical Genre for Children and the Process of Civilization (New York: Wildman Press, 1983 